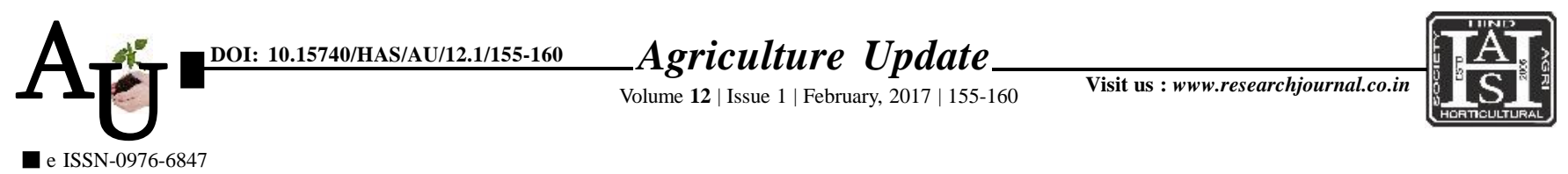

\title{
Research Article: Extent of production and marketing of the produce and reasons for success or failure of the SHGs
}

\author{
Q RADHIKA BHONGALE, D.P. HARDIKAR AND Y.J. WAGHMODE
}

Article Chronicle: Received : 01.01.2017;

Revised : 15.01.2017; Accepted : 23.01.2017

KeY Words : Extent, Production, Marketing, Reasons for success, Failure, Self-helf groups

Author for correspondence :

\section{RADHIKA BHONGALE} Department of Extension Education, College of Agriculture, Dr. B.S. Konkan Krishi Vidyapeeth, Dapoli, RATNAGIRI (M.S.) INDIA Email:radhikabhongale @ gmail.com

See end of the article for authors' affiliations
SUMMARY : The present study was conducted in Dapoli and Guhagar tahsils of Ratnagiri district (Konkan region) and Baramati and Indapur tahsils of Pune district (Western region) of Maharashtra. The sample constituted of 120 SHGs heads from 12 villages. With regards to the average capital investment made under different activities, 'dairy' stood first with the investment of Rs. 2.15 lakh. This was followed by 'mess' (Rs. 1.81 lakh), 'goat rearing' (Rs. 1.57 lakh), 'others' (Rs. 1.39 lakh), 'retail shops' (Rs. 1.36 lakh), 'snacks centre' (Rs. 1.33 lakh), 'tailoring' (Rs. 1.13 lakh), 'Masala making' (Rs. 1.09 lakh), 'syrup making' (Rs. 0.97 lakh), 'preparation of diwali stuffs' (Rs. 0.91 lakh), 'Shevai making' (Rs. 0.77 lakh). The capital investment with respect to the trades namely, 'fish selling', 'vegetable cultivation' and 'Papad making' was comparatively low, that is, Rs. 0.41 lakh, Rs. 0.56 lakh, Rs. 0.62 lakh, respectively. Four-fifth $(80.83 \%)$ of the respondents experienced, 'low participation of members in the group' as constraint. Followed by 'members are irregular in attending the meetings' (53.53\%) and 'lack of organization of training programme' $(47.50 \%)$. The other constraints faced by the respondents were, 'lack of encouragement from society members for taking up group activity' $(40.83 \%)$ followed by 'the schemes for welfare of woman folk are not executed properly' (34.16\%) and 'lack of proper guidance by implementing agencies' $(13.33 \%)$.

How to cite this article : Bhongale, Radhika, Hardikar, D.P. and Waghmode, Y.J. (2017). Extent of production and marketing of the produce and reasons for success or failure of the SHGs. Agric. Update, 12(1): 155-160; DOI : 10.15740/HAS/AU/12.1/155-160. 